\section{Response of Creeping Bentgrass to Spring-applied Herbicides}

\author{
Sang Ryul Shim ${ }^{1}$ \\ Chongju University, Korea
}

\author{
B.J. Johnson ${ }^{2}$ \\ Department of Agronomy, University of Georgia, Georgia Station, \\ Griffin, GA 30223-1797
}

Additional index words. Agrostis palustris, phytotoxicity

\begin{abstract}
Creeping bentgrass (Agrostis palustris Huds.) putting greens are commonly infested with crabgrass (Digitaria spp.) and goosegrass [Eleusine india (L.) Gaertn.]; however, many herbicides have the potential to severely injure this turfgrass species. A field investigation was conducted over 2 years to determine the tolerance of creeping bentgrass to various herbicides. Trifluralin plus benefin $\left(2.2\right.$ to $\left.6.7 \mathrm{~kg}^{-h^{-1}}{ }^{-1}\right)$, dithiopyr $\left(0.37\right.$ to $\left.1.1 \mathrm{~kg}^{\circ} \mathrm{ha}^{-1}\right)$, and prodiamine $\left(0.5\right.$ to $\left.1.7 \mathrm{~kg} \cdot \mathrm{ha}^{-1}\right)$ did not injure creeping bentgrass. Pendimethalin caused only slight injury when applied at $3.4 \mathrm{~kg} \cdot \mathrm{ha}^{-1}$, but injury increased in 1 of 2 years when applied at $\geq 6.7 \mathrm{~kg} \cdot \mathrm{ha}^{-1}$. Creeping bentgrass was severely injured when treated with benefin plus oryzalin $\left(\geq 4.5 \mathrm{~kg}^{\circ} \mathrm{ha}^{-1}\right)$, fenoxaprop $\left(0.07 \mathrm{~kg} \cdot \mathrm{ha}^{-1}\right)$, and oxadiazon $\left(3.4 \mathrm{~kg} \cdot \mathrm{ha}^{-1}\right)$ granular and WP formulations and, therefore, should not be applied to the turf. Chemical names used: $N$-butyl- $N$-ethyl-2, 6dinitro-4-(trifluoromethyl) benzenamine (benefin); S,S -dimethyl 2-(difluoromethyl-4(2-methylpropyl)-6-(trifluoromethyl-3, 5-pyridinedicarbothioate (dithiopyr); ( \pm ) 2-[4[(6-chloro-2-benzoxazolyl)oxy]phenoxy]propanoic acid (fenoxaprop); 4-(dipropylamino)-3,5-dinitrobenzenesulfonamide (oryzalin); 3-[2,4-dichloro-5-(1-methylethoxy)phenyl]-5-(1,1-dimethylethyl)-1,3,4-oxadiazol-2-(3H)-one (oxadiazon); $N$-(1ethylpropyl)-3,4-dimethyl-2,6-dinitrobenzenamine (pendimethalin); 2,4-dinitro $N, N$-dipropyl-6-(trifluoromethyl)-1,3-benzenediamine (prodiamine); 2,6-dinitro- $N-N$-dipropyl-4-(trifluoromethyl)benzenamine (trifluralin).
\end{abstract}

Creeping bentgrass is widely grown throughout the transitional zone of the south-

\footnotetext{
Received for publication 17 May 1991. Accepted for publication 27 Sept. 1991. Supported by state and Hatch Act funds allocated to the Georgia Agricultural Experiment Stations. I thank J. Davis, station statistician, for his cooperation in these studies and gratefully acknowledge T. Dinkins and M. Gilmer for technical assistance. The cost of publishing this paper was defrayed in part by the payment of page charges. Under postal regulations, this paper therefore must be hereby marked advertisement solely to indicate this fact.

Associate Professor.

${ }^{2}$ Professor.
}

eastern United States (Mazur, 1986). To maintain good-quality bentgrass golf greens, it is often necessary to apply herbicides for weed control. Tolerance of creeping bentgrass to herbicides is normally more important than weed control, due to sensitivity of this species to herbicides.

Dithiopyr, $O, O$-bis(1-methylethyl S-[2[(phenylsulfonyl) amino]ethyl] phosphorodithioate (bensulide), and bensulide plus oxadiazon are the only preemergence herbicides presently labeled for bentgrass greens. Bensulide injury to bentgrass has varied from none (Bingham and Schmidt, 1983) to severe (Callahan, 1972); however, none to slight discoloration was observed with bensulide plus oxadiazon (Johnson, 1987, 1990). Neither bensulide nor bensulide plus oxadiazon was included in the present study because of limited space for experiments. Bensulide has poor activity on goosegrass (Johnson and Murphy, 1987), and bensulide plus oxadiazon was previously evaluated on creeping bentgrass (Johnson, 1987).

Oxadiazon has been evaluated on bentgrass for several years. In Tennessee, the herbicide did not cause any significant discoloration or sod loss during 3 years (Callahan, 1986). In Georgia, injury from oxadiazon varied from slight to moderate, but the turf fully recovered with no stand loss (Johnson, 1987). In a later Georgia experiment, oxadiazon reduced density of creeping bentgrass when the turf was maintained at a below-normal [<294N-12P-124K $\left.\left(\mathrm{kg} \cdot \mathrm{ha}^{-1}\right)\right]$ fertility level (Johnson, 1990). The response to oxadiazon was unacceptable for creeping bentgrass within 3 weeks after treatment (WAT) in Maryland, but the turf recovered by 5 WAT (Demoeden, 1987). Oxadiazon did not affect creeping bentgrass root growth (Dernoeden et al., 1988).

Pendimethalin applied at $1.7 \mathrm{~kg} \cdot \mathrm{ha}^{-1}$ in early May injured creeping bentgrass only slightly 3 WAT (Demoeden, 1987). However, the injury increased significantly in July when the turf was treated with a second application at the same rate in late June. Prodiamine applied in early May at 0.6 to 1.1 $\mathrm{kg} \cdot \mathrm{ha}^{-1}$ did not injure creeping bentgrass by late May, but severe injury occurred in July following a second application at the same rates in late June (Demoeden, 1987). Fenoxaprop at $\geq 0.06 \mathrm{~kg} \cdot \mathrm{ha}^{-1}$ also caused unacceptable discoloration and reduced density of creeping bentgrass (Dernoeden, 1987; Higgins et al., 1987). Oryzalin at $2.2 \mathrm{~kg} \cdot \mathrm{ha}^{-1}$ was reported to reduce shoot and root weights of creeping bentgrass (Finney and Callahan, 1988).

Bentgrass often experiences severe summer stresses in the Piedmont region, which may be enhanced by herbicides. Therefore, additional information is needed on tolerance of creeping bentgrass to preemergence her- 
Table 1. Influence of herbicide treatments on injury of creeping bentgrass (Griffin, Ga.).

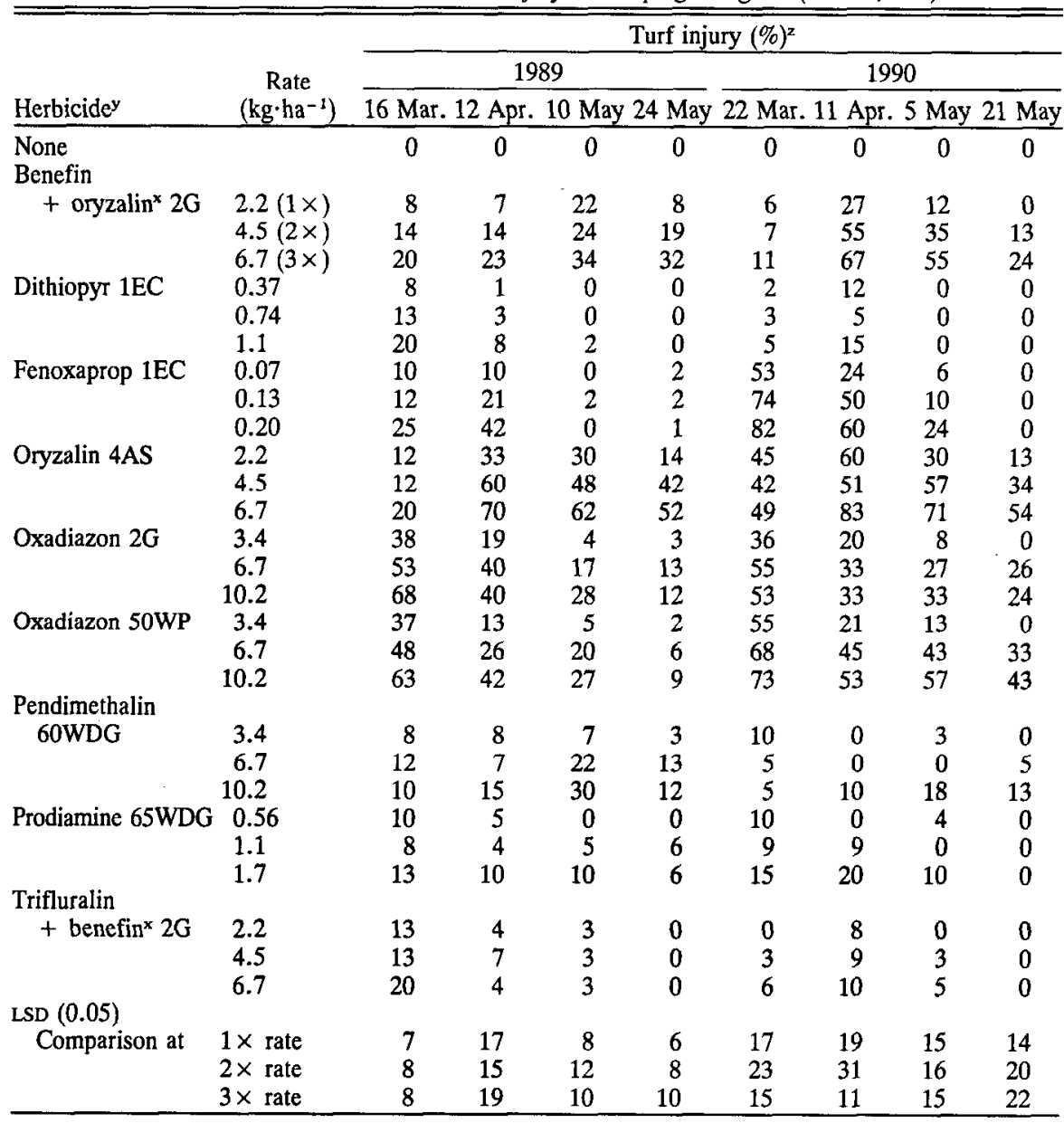

zTurf injury ratings were based on $0=$ no injury, $1 \%$ to $20 \%=$ slight injury, $21 \%$ to $30 \%=$ moderate injury, $>30 \%=$ severe injury and not acceptable. Data are means of three observations.

yerbicides were applied 7 Mar. 1989 and 1 Mar. 1990.

${ }^{x}$ Combined rates for mixed herbicides.

bicides (Johnson and Murphy, 1989; Watschke et al., 1988). Our objectives were to determine the tolerance of creeping bentgrass maintained as a putting green to several herbicides and the time interval required for the turf to recover from possible herbicide injury.

Established 'Penncross' creeping bentgrass was treated with one of nine herbicides (Table 1) on 7 Mar. 1989 and 1 Mar. 1990 at Griffin, Ga. Each herbicide was applied to the same plots both years at low, medium, and high dosages: low $=$ recommended label rate; medium = two times the recommended label rate; and high $=$ three times the recommended label rate. Oxadiazon $(2 \mathrm{G})$, benefin plus oryzalin $(1+1=2 \mathrm{G})$, and trifluralin plus benefin $(0.7+1.3=2 \mathrm{G})$ were applied as granules by hand. Fenoxaprop (1EC), dithiopyr (1EC), oryzalin (4AS), oxadiazon (50WP), pendimethalin (60WDG), and prodiamine $(65 \mathrm{WDG})$ were applied as broadcast spray in 188,355 , and 563 liters of water/ha for the low, medium, and high rate, respectively. The difference in water volume was based on the solution concentration of the low rate, which was repeated as necessary to apply other rates. All herbicides were applied to dry turf and watered in $12 \mathrm{~h}$ after treatment.
Creeping bentgrass was fertilized with 294N-12P-123K (kg.ha' ${ }^{-1} \cdot$ year $\left.^{-1}\right)$. Nitrogen was applied at $14 \mathrm{~kg} \cdot \mathrm{ha}^{-1}$ in March, June, and August; $26 \mathrm{~kg} \cdot \mathrm{ha}^{-1}$ in February and December; and $50 \mathrm{~kg} \cdot \mathrm{ha}^{-1}$ in April, September, October, and November. Phosphorus was applied at $6 \mathrm{~kg} \cdot \mathrm{ha}^{-1}$ in April and September, and $\mathrm{K}$ was applied at $41 \mathrm{~kg} \cdot \mathrm{ha}^{-1}$ in February, August, and November. The fertilizer sources were 34-0-0 (ammonium nitrate), 0-0-50 (muriate potash), 6-2-0 [Milorganite (Milwaukee Metropolitan Sewerage District, Milwaukee)], 18-4-10 (Lesco, Rocky River, Ohio), and 22-0-16 (O.M. Scott, Marysville, Ohio).

The creeping bentgrass root zone was a U.S. Golf Association soil mixture. The soil composition was $970 \mathrm{~g}$ sand $/ \mathrm{kg}, 20 \mathrm{~g}$ silt/ $\mathrm{kg}$, and $10 \mathrm{~g}$ clay/kg. Organic matter content was $80 \mathrm{~g} \cdot \mathrm{kg}^{-1}$.

Actively growing creeping bentgrass was mowed three times per week at a 4-mm height with clippings removed. Irrigation was applied as needed to prevent wilting, and fungicides and insecticides were used to prevent disease and insect problems.

Visual ratings for creeping bentgrass injury was made on selected dates from midMarch until late June. Turf injury (discoloration and foliar injury) was based on 0 to
$100 \%$, where $0=$ no injury, $1 \%$ to $20 \%=$ slight injury, $21 \%$ to $30 \%=$ moderate injury, $>30 \%=$ severe injury and commercially unacceptable, and $100 \%=$ complete kill.

The experimental design was a strip split block with three replications. Herbicides were randomized within blocks for the whole plots $(0.9 \times 4.5 \mathrm{~m})$, and herbicide rates were randomized within blocks perpendicular to whole plots for subplots $(0.9 \times 1.5 \mathrm{~m})$. Analysis of variance procedure of SAS was used to analyze the data (SAS Institute, Inc., 1982). Because there were significant year interactions, treatment means were separated by LSD at $P=0.05$ by year. Data was analyzed within dates to determine changes that occurred immediately after treatment until 3 months later.

Creeping bentgrass was injured slightly with dithiopyr, prodiamine, and trifluralin plus benefin, regardless of rate, when ratings were made mid- to late Mar. 1989 and 1990 (Table 1). The slight injury that occurred from these herbicides in March gradually decreased by-mid-April to early May. These results with prodiamine agree with those reported from Maryland, when the herbicide was applied at 0.6 to $1.1 \mathrm{~kg} \cdot \mathrm{ha}^{-1}$ once in early May (Dernoeden, 1987). However, it is not uncommon for creeping bentgrass to be injured more when an herbicide is applied after temperatures are high in early summer as compared to spring when temperatures are lower. More injury occurred from a second prodiamine application in Maryland (Dernoeden, 1987) and a second oxadiazon $G$ application in Georgia (Johnson, 1987).

Pendimethalin at $3.4 \mathrm{~kg} \cdot \mathrm{ha}^{-1}$ injured creeping bentgrass only slightly (Table 1). Injury increased by 10 May 1989 , when the pendimethalin rate was $\geq 6.7 \mathrm{~kg} \cdot \mathrm{ha}^{-1}$. Pendimethalin at $3.4 \mathrm{~kg} \cdot \mathrm{ha}^{-1}$ was safe in both years.

The tolerance of creeping bentgrass to benefin plus oryzalin was similar to that of pendimethalin in 1989 (Table 1), when the grass was injured only slightly with benefin plus oryzalin at $2.2 \mathrm{~kg} \cdot \mathrm{ha}^{-1}$, but the injury increased to the moderate and severe levels when the rate was increased to 4.5 and 6.7 $\mathrm{kg} \cdot \mathrm{ha}^{-1}$, respectively. We do not know why benefin plus oryzalin injured the turf more in 1990 than the previous year. Mean air temperatures for the four weeks after treatment each year were similar. Although the herbicides were applied to the same plots both years, the turf fully recovered by midJune 1989 (data not shown). Due to excessive turf injury, benefin plus oryzalin would not be recommended on creeping bentgrass greens.

Oxadiazon severely injured creeping bentgrass regardless of rate or formulation when ratings were made 1 to 3 WAT in 1989 and 1990 (Table 1). At $3.4 \mathrm{~kg} \cdot \mathrm{ha}^{-1}$, oxadiazontreated turf recovered to an acceptable level by mid-April. Although the initial injury was more severe as rates increased, there were no differences in injury due to oxadiazon formulation ( $2 \mathrm{G}$ or $50 \mathrm{WP}$ ) in 1989. However, more injury existed during Mar. 1990 
in plots treated with the 50WP formulation than with $2 \mathrm{G}$ formulation. Creeping bentgrass treated with $3.4 \mathrm{~kg} \cdot \mathrm{ha}^{-1}$ recovered by early May regardless of formulation, while turf treated above $3.4 \mathrm{~kg} \cdot \mathrm{ha}^{-1}$ resulted in more injury. These results show that creeping bentgrass was severely injured with oxadiazon regardless of formulation. Similar results were reported on creeping bentgrass in Maryland (Dernoeden, 1987).

Oryzalin and fenoxaprop severely injured creeping bentgrass in 1989 and 1990 (Table $1)$. Turfgrass treated with fenoxaprop recovered to an acceptable level by early May, whereas turf treated with oryzalin did not. Oryzalin or fenoxaprop at levels evaluated in this study should not be applied to creeping bentgrass greens.

Results from this study show that trifluralin plus benefin, dithiopyr, and prodiamine were safe to apply at 1 to $3 \times$ label rates when applied singly in early March for the control of crabgrass in creeping bentgrass (Johnson and Murphy, 1989; Watschke et al., 1988). Dithiopyr and prodiamine have demonstrated effective control of goosegrass (Johnson and Murphy, 1989) and, in this experiment, showed minimal injury to creeping bentgrass. We emphasize that creeping bentgrass may be injured and loss of stand may occur if these herbicides are applied in late winter or early spring with an additional application repeated in late spring or early summer. Therefore, application timing for these herbicides is important for optimum bentgrass tolerance and should be limited to a single application in late winter or early spring. Oxadiazon (G or WP formulation), pendimethalin, fenoxaprop, oryzalin, and benefin plus oryzalin showed unacceptable injury to turf and, therefore, should not be applied to creeping bentgrass.

\section{Literature Cited}

Bingham, S.W. and R.E. Schmidt. 1983. Influence of preemergence herbicides on root development of Agrostis stolonifera sod. Weed Res. 23:339-346.

Callahan, L.M. 1972. Phytotoxicity of herbicides to a 'Penncross' bentgrass green. Weed Sci. 20:387-391

Callahan, L.M. 1986. Crabgrass and goosegrass control in a bentgrass green in the transition zone. Agron. J. 78:625-628.

Demoeden, P.H. 1987. Phytotoxic effects of some herbicides applied to bentgrass. Proc. Northeastern Weed Sci. Soc. 41:224-228.

Demoeden, P.H., D.B. Davis, and J.D. Fry. 1988. Rooting and cover of three turf species as influenced by preemergence herbicides. Proc. Northeastern Weed Sci. Soc. 42:169-173

Finney, S.A. and L.M. Callahan. 1988. Cellular response of two turfgrass cultivars to selected preemergence herbicides, p. 40-44. In: L.M Callahan (ed.). 1988. Turfgrass management annual research summary report. Tennessee Res. Rpt. 89-09.

Higgins, J.M., L.B. McCarty, T. Whitwell, and L.C. Miller. 1987. Bentgrass and bermudagrass putting green turf tolerance to postemergence herbicides. HortScience 22:248-250.

Johnson, B.J. 1987. Tolerance of bentgrass to dates and frequency of preemergence herbicide treatments. Agron. J. 79:992-996.
Johnson, B.J. 1990. Herbicide $\times$ annual fertility programs influence on creeping bentgrass performance. Agron. J. 82:27-33.

Johnson, B.J. and T.R. Murphy. 1987. Control of large crabgrass and goosegrass in warm-season turfgrasses. Georgia Agr. Res. Bul. 364.

Johnson, B.J. and T.R. Murphy. 1989. Summer annual weed control in turfgrass. Georgia Agr. Res. Bul. 388.
Mazur, A.R. 1986. Bentgrass management in the hot, humid Southeast. Florida Turf Digest 3(9):20-22.

SAS Institute, Inc. 1982. SAS users guide. SAS Institute, Inc., Cary, N.C.

Watschke, T.L., G. Hamilton, and S. Harrison. 1988. Preemergence control of crabgrass in a mixed stand of cool-season turfgrasses. Proc. Northeastern Weed Sci. Soc. 42:166-167. 